\title{
UM CAUSO, UM POVO, UMA TELEVISÃO: FORMAS ANÁLOGAS*
}

Ana Carneiro

Repara bem no que não digo.

Paulo Leminski

A antiga Fazenda dos Buracos está situada em um cânion cavado pelo rio Pardo, que corta a extensa área de chapada — "o geralzão" — antigamente coberta pelo cerrado e hoje dominada por grandes monoculturas de soja e capim. Mais preservada, a terra dos Buracos segue o Pardo, que vai recebendo outros rios até desaguar no médio São Francisco, cerca de 150 quilômetros longe dali, perto de Januária. A fazenda foi comprada por João Branco, avô dos que hoje são "os antigos" do lugar. João trouxe com ele a esposa e dois outros casais - um formado pela irmã dele, outro pelo irmão dela — que se estabeleceriam ali como "agregados"1 dos primeiros, morando nas beiradas do rio Três Passagens, em áreas menos férteis que as dos proprietários da fazenda. Ao longo das últimas quatro gerações, os descendentes desses três casais foram casando entre si, compondo o hoje chamado "povo dos Buracos", que se espalha por cerca de 50 casas entre o Pardo e seus afluentes. É tudo primo, dizem-me os buraqueiros.

Inicialmente soava-lhes estranho que uma moça do Rio de Janeiro estivesse vivendo entre eles, diante do que eu me justificava sobre meu trabalho, pesquisar o parentesco do povo dos Buracos. Eles em geral assentiam com a cabeça e me orientavam, Você tem que ouvir os causos dos antigos! Esses povo antigo e velho é que sabem contar os causos do povo! Depois de alguns meses nos quais visitei e conversei tanto com os antigos quanto com seus filhos, netos e bisnetos, alguns buraqueiros me cumprimentaram pelo feito, De tanto caminhar e prosear nas casas tudo, daqui a um pouco você vai estar conhecendo o povo dos Buracos melhor do que os daqui!

Para chegar ao "povo", portanto, tive desde o início que atravessar os "causos". Explorarei aqui a articulação entre estes termos, com ênfase neste último, tratando-os como conceitos nativos particularmente frutíferos quando 
postos em diálogo com nossas próprias maneiras de pensar e descrever as formas sociais que observamos. ${ }^{2}$ Tratar esses termos como conceitos exige um sobre-esforço de delimitação que não deve, entretanto, ser mais do que provisório. Afinal, nada mais vago do que o sentido e a forma que podemos atribuir ao termo "causo". Pode consistir em uma única e trivial frase, Fulano foi ontem na casa de Cicrano, ele mesmo me contou o causo, diz-se ordinariamente, Fulano foi trazantontem na casa de Cicrano, foi Beltrano quem me disse, Fulano mesmo foi quem contou o causo pra Beltrano. ${ }^{3}$ Ou pode consistir em preleções de mais de hora, desenvolvendo detalhadamente as histórias e suas piadas. Assim é o "causo dos antigos", fruto de uma prosa prolongada. Na casa de farinha, por exemplo, O café molha boca, a mandioca secando e o povo barulhando até umas horas. Oh, não existe trem mais fofoqueiro do que farinha! No dia seguinte, os anfitriões comentam a situação de conversa com orgulho, Ficamos contando causo um bocado de horas, matei um frango e o povo entrou forte na prosa!

Assim, mais do que buscar limites formais para a definição do causo, como se este fosse um gênero, investigarei aqui as práticas criativas desta forma narrativa, isto é, as conversas triviais nas quais surgem os causos. Neste sentido, vale adiantar que contar causo e partilhar o momento de comer são gestos que indicam relações de proximidade; mais do que isto, promovem e qualificam relações pessoais conforme agregam. Contudo, por isto mesmo, também ameaçam bem-quereres com o risco de ruptura, de "desentendimento" uma palavra mal dita pode provocar tensões ou mesmo brigas físicas, em casos extremos pode surgir a "fofoca": teria a cozinheira e anfitriã oferecido "comida benzida"? Quaisquer "conhecidos" que por ventura se esbarrem na estrada tratarão de trocar rapidamente dois dedos de prosa, e cada um contará seu causo, isto é, dirá de onde veio, para onde vai, quem encontrou pelo caminho, quem pretende encontrar. Notícias prosaicas que cada uma das partes repetirá adiante, a quem mais encontrar, seguindo a fórmula do causo, Fulano esteve com Cicrano, foi ele mesmo quem me disse, conversei com ele hoje mesmo vindo para cá. Como veremos, esta maneira de retraçar o trajeto da informação é uma característica comum a quaisquer dessas formas, sejam os causos das prolongadas conversas ao calor do fogão ou os que são rápidos comentários, feitos, por exemplo, em um encontro fortuito.

\section{O que é um causo?}

Os causos dos antigos falavam-me sobre episódios ocorridos há décadas atrás, cujos protagonistas eram parentes próximos ou distantes, mas sempre 
ligados por relações familiares, isto é, vínculos de descendência e/ou afinidade. Os narradores traçavam o elo com precisão e detalhe, citando nomes das pessoas de cada geração até chegar, do passado ao presente, a alguém que eu conhecesse pessoalmente. Deste modo forneciam-me "conhecimento" sobre as partes envolvidas no causo, ou seja, incluíam-me na rede de relações singular produzida pela nossa conversa. Assim me davam a chance de escutar, com mais interesse e poder de análise, a história puxada pela memória a partir do rumo de nossa prosa. Era um traçado genealógico muitas vezes longo e tortuoso, misturando descendentes e afins, vizinhos e amigos, primos e cunhados, genros e sobrinhos, e daí por diante. Como me disse certa vez Seo Zé de Ataíde, O tio de um é irmão de outro,Veja como é a palavra, uma mesma pessoa é tio de um e é irmão do outro (pai do primeiro).

As linhas de parentesco formavam assim um emaranhado de classificações que se sobrepunham ou, quando se alternavam, uma eclipsava a outra, turvando meu entendimento. Contudo, sempre havia por parte de meu interlocutor um detalhamento atencioso para que eu pudesse situar a pessoa de quem se falava. Muitas vezes, o traçado da cadeia de vínculos familiares - que ligavam o personagem narrado até alguém que eu conhecesse - era feito nas duas direções: do presente para o passado e do passado para o presente. Os diversos caminhos e termos de parentesco pelos quais a pessoa narrada era situada funcionavam como pequenas versões dentro de uma mesma versão do causo, sendo esta, com frequência, desenvolvida pelo narrador em função do que ele sabia já me ter sido narrado anteriormente por outros narradores, cujas relações com a pessoa narrada variavam quanto à nova versão.

Não era apenas comigo que o povo antigo buraqueiro se preocupava em fornecer evidências dos causos dos antigos. De um modo geral, nas narrativas buraqueiras, as pessoas/personagens ganham consistência quando localizadas em relação ao narrador e aos ouvintes, Sabe a Fulana, filha de Beltrana? Ela é casada com Cicrano, tio meu! Esta é uma das fórmulas recorrentes ao se iniciar um causo. Nesta rede virtualmente infinita, o ocorrido narrado revive através da cadeia de pessoas que conversaram: do ouvinte atual àquela que viveu o acontecido. Assim, ao aproximar os envolvidos na conversa, o "causo" funciona como um dispositivo de circulação e mapeamento de pessoas conectadas a um certo circuito de troca de prosa. Os mais jovens, nos momentos mais animados de congraçamento familiar, buscavam, com um pouco mais de facilidade do que eu, deslindar a teia de relações pessoais e comunicativas que se estendiam a partir dos conhecidos de hoje. A narrativa empenhava assim um movimento de aproximação entre os ouvintes, os personagens e o narrador, que com o mesmo recurso situava 
a si mesmo no interior do mapa, A velha era do povo dos Fulano, era prima primeira do pai de meu avô, morava tudo ali nas beiras do Retiro, foi meu avô quem me contou o causo da velha. Referências ao avô, ao pai, à prima, ao povo, todos da beira do Retiro, associando o passado a pessoas e paisagens atuais, davam-me "conhecimento", à medida que se conectavam à minha própria experiência, de uma história do "povo de primeiro".

A aproximação narrativa entre interlocutores, narradores e narrados do causo, efetuada pelo traçado das relações que os ligam, é o que fornece as evidências: informam como o causo foi transmitido através de que trocas de conversa, baseadas em que grau de intimidade e de parentesco, refletido em que configuração do espaço geográfico dos Buracos. Assim, o povo buraqueiro vai se deslindando em outros povos, todos parentes, todos "um sangue só", mas devidamente distinguidos de acordo com os rios ou as veredas que dão nome aos seus locais de moradia, à sua vizinhança, e pelos respectivos modos de comer e de conversar de famílias e vizinhanças. Os nomes de rios indicam uma "vizinhança" não apenas geográfica, mas também um trânsito intenso e diário entre casas, próximas fisicamente e também afetivamente, "um sangue só", constituindo assim uma mesma "família", Quem casa quer casa, diz o dizer.

Por este motivo, o território do povo se altera o tempo todo, os casamentos vão promovendo deslocamentos - em geral a esposa indo morar vizinha aos sogros - e misturando famílias, reconfigurando constantemente a ocupação do espaço e o agrupamento de vizinhanças, a circulação da prosa e da comida. Os causos dos antigos retomam e atualizam esse processo infindável de constituição do povo, falam sobre trechos isolados nesta teia de relações estendidas no espaço e no tempo, ligando falantes, narrados e ouvintes, O falecido compadre Zé, irmão da velha Maria, essa do causo, ele morava ali onde é hoje a casa de Pedrim, mas a casa ele construiu para cá daquele pé de Jatobá, Pedrim é dos povo de compadre Zé também.

Contar causo implica estender uma teia narrativa rumo ao passado e ao futuro, pois "contar" é lançar adiante. Em suas várias versões, o causo segue se diferenciando - a cada contar o narrador tem uma voz provisória, e é esta mesma que espalha o causo, multiplicando as vozes que o narram a seguir e sobrepondo-se às primeiras. Por certo, está em jogo um significativo processo de transmissão de memória, mas as elaborações dos próprios buraqueiros sobre seu gosto em contar e ouvir causos têm outros objetos de preocupação. Se o intuito é seguir as problematizações sobre o causo conforme as conceituações nativas, como é o caso aqui,vale considerar que estas não narram nem pretendem narrar histórias de vida ou biografias, mas antes "bestar", "deixar o tempo passar", para isto entrecortando causos 
ordinários sobre fatos diários, alguma associação levando alguém a puxar um episódio mais antigo, no qual uma teia maior de relações é envolvida no que se conta. ${ }^{4}$

Para além da explicitação de minha curiosidade sobre o assunto, o próprio desenrolar da conversa buraqueira não raro rumava para uma espécie de metarreflexão, Ê como é bom ficar contando causo sem menino pra cuidar! ou, A gente aqui de casa não tem nada que dê mais prazer do que receber uma visita pruma boa prosa como essa! Sinalizavam sobretudo a falta de pretensão a uma função informativa, isto é, de um conteúdo particular que pudéssemos comparar ao de uma memória, A gente conta causo é pra bestar! Prosear pra entreter! Pro tempo passar! É mode ficar bestando, dar risada. Assim eles me diziam sobre seu prazer em participar de "uma boa prosa".

Quando se fala nos causos contados "nas casas", dentre os quais os "dos antigos", a importância desta ausência de preocupação em informarcomentada pelos buraqueiros antes que eu lhes colocasse a questão - está na implicação que isto tem na forma narrativa definidora do causo. Ora, se a prática de contar causos tem como único intuito divertir o interlocutor, sua forma não pode supor recursos narrativos específicos, pois eles sempre dependerão de como e o que divertirá os ouvintes naquela situação singular. É neste sentido que os causos são performáticos (e.g. Bauman1986): buscam a forma da narrativa como se buscassem o conhecimento que emerge da ação - a experiência a um só tempo se faz ação e narrativa.

A forma do causo é, assim, irredutivelmente variável, nunca se repete, já que está em função exclusivamente das relações e das associações contingentes efetuadas no ato único de uma conversa qualquer. Por este motivo, creio ser interessante voltarmo-nos antes para os dispositivos de criação desta forma narrativa e não para determinações sobre uma suposta forma-modelo do causo. Bruce Mannheim e Krista Van Vleet (1998) colocam este mesmo problema em sua análise precisa sobre os "eventos complexos" (cf. Bakhtin 1981) em que se constituem as narrativas orais quéchua investigadas por eles. Lembrando trabalhos como os de Julia Kristeva $(1969,1970)$ e Charles Briggs e Richard Bauman (1990), os autores chamam a atenção para os diálogos implícitos ou escondidos que são trazidos à tona através de outras narrativas coexistentes às quais se faz menção durante a conversa. Há um problema, argumentam, no ponto de partida de trabalhos que privilegiam a leitura representacional das narrativas orais, tomando-as como se fossem um gênero escrito, um "artefato textual" — text artifacts (Silverstein \& Urban 1996:3 apud Mannheim \& Van Vleet 1998:326). ${ }^{5}$

Buscando "textos completos", a escuta do(a) etnográfo(a) deixa de lado a responsabilidade dele(a) mesmo(a) na criação da situação em que a narrativa 
monológica se torna possível. Isto impede que se explorem as situações ordinárias nas quais os trechos de estórias surgem — como que naturalmente da conversa (Mannheim \& Van Vleet 1998:327). Como já observou Michel de Certeau (1988:63-64), os pressupostos que limitam nossas concepções do "contar causos" (story telling) costumam interferir em nossas pesquisas e nos recortes analíticos mais do que nos damos conta. Frequentemente, notam Mannheim e Van Vleet (1998:326), ignora-se o complexo padrão de participação através do qual o diálogo se realiza. No evento de fala, cara a cara, os falantes evocam múltiplas estruturas de interação, não só entre os indivíduos presentes, mas entre suas distintas atuações (roles), produzidas como sombras ao longo da conversa.

No caso dos causos, há uma aproximação afetiva entre falantes e ouvintes, produzindo uma experiência mútua de conhecimento sobre as relações narradas e criadas pelo diálogo. É importante, porém, que esta dimensão performática dos causos não nos leve a enxergá-los como momentos ritualizados, destacados da vida ordinária. Ao contrário, eles são constitutivos da dinâmica cotidiana e, assim, se repetem de casa em casa e também nas caminhadas, através dos deslocamentos diários dos parentes na vizinhança. Os causos constituem, por estes caminhos, uma cadeia narrativa de ilimitadas e paralelas variações. ${ }^{6}$

A ideia de uma narrativa em variação constante, a exemplo das transformações mitológicas descritas por Claude Lévi-Strauss (1964, 1967, 1968, 1971), permite-nos aqui uma comparação pontual com a etnologia ameríndia. Inspirando-se na análise de Peter Gow (1991), que havia explorado a presença rotineira e despretensiosa das narrações míticas, Marina Vanzolini (2013) reflete sobre a relação entre a variação mitológica e as constantes acusações mútuas de mentira feitas entre os narradores aweti do alto rio Xingu. Os mitos não têm a função de instruir, afirma a autora, no sentido de que sua relação com o mundo não é uma relação referencial, mas eles assumem um potencial orientador que deve ser investigado. Este potencial de conhecimento é encontrado por Vanzolini a partir da percepção de que a palavra tomowkap, em geral traduzida pelos Aweti como "história", é formada pela raiz do verbo "orientar" - mowka. O curioso é que este termo, observa, é usado para relatos seja sobre episódios prosaicos ocorridos dez minutos atrás, seja sobre histórias dos antepassados, que os Aweti chamam mote mo'aza etomowkap e que poderia ser traduzido, diz a autora, por "história dos antigos". O mito, enfim, é uma categoria tão pouco delimitável quanto o causo.

Não há dúvidas de que os objetos de conhecimento (os mundos) dos Aweti e do povo dos Buracos são completamente distintos entre si, bem como 
o que podemos extrair deles a respeito da relação entre verdade e mentira: entre os Aweti, a inexistência de um termo traduzível por "verdade" (no sentido da alétheia) coloca um problema específico sobre a variação do mito. Nos Buracos, ao contrário, o questionamento sobre a verdade - como relação exata entre signo e significante - surge frequentemente pelos que ouvem o causo, impondo ao narrador uma necessidade constante de evidenciação do que é contado a partir de referências na "realidade". Tais evidências estão nas pessoas e nas paisagens existentes no presente. A verdade referencial é um conceito importante para os buraqueiros, podemos mesmo dizer que é ela que orienta as variações formais de cada narrador, isto é, suas formas de persuasão diante de seus interlocutores. Não devemos, contudo, deduzir daí que a referência em questão seja um mundo cuja real existência esteja fora das experiências particulares dos que o observam. Muito pelo contrário, como me parece sugerir a necessária vinculação feita pelos buraqueiros entre o causo, as relações pessoais e o divertimento.

É neste sentido que a ênfase de Gow e Vanzolini no caráter prosaico da ideia de mito nos dá a pista para a análise do causo. Nisto reside um elemento importante de uma imagem singular do conhecimento. Nos Buracos, deve-se por este caminho notar o humor como aspecto fundamental da produção e da transmissão do conhecimento - sociológico, por assim dizer - que se pode eliciar da circulação de causos. Neste sentido, a aproximação com a etnografia ameríndia também nos é interessante. Pierre Clastres (2003 [1974]) adianta-nos esta dimensão: quão inspirador pode ser o riso no tratamento do mito como pensamento. Desde que, graças às Mitológicas de Lévi-Strauss, o mito ganhou novo prestígio, sabemos que, escreve o autor, "os mitos não falam para nada dizerem [...]. Talvez, entretanto, o interesse muito recente que suscitam os mitos corra o risco de nos levar a tomá-los muito a sério desta vez e, por assim dizer, avaliar mal sua dimensão de pensamento" (Clastres 2003 [1974]:147).

Dito isto, o autor faz uma análise estrutural de dois mitos chulupi, recolhidos em 1966 no sul do Chaco paraguaio. Estes mitos são contados e ouvidos repetidas vezes, conta ele, e o efeito é sempre o mesmo: "os sorrisos do início passam a cacarejos mal reprimidos, o riso explode em francas gargalhadas que acabam se transformando em uivos de alegria" (:148). Em sua análise, ele mostra que a comicidade dirige-se em ambos os casos (ou mitos) ao medo e ao respeito que inspiram jaguares e xamãs (cada um protagonista de um dos mitos). Os índios, conclui, matam tais personagens, seja realmente - quando um xamã é perigoso ou quando se defronta com um jaguar na floresta - seja simbolicamente, através do riso e de sua desmistificação. O mito "desvaloriza no plano da linguagem aquilo que não 
seria possível na realidade e, revelando no riso um equivalente da morte, ensina-nos que, entre os índios, o ridículo mata".

Nos Buracos o riso possui um poder desmistificador que pode ser aproximado do dos Chulupi, entretanto, seu recurso narrativo não busca matar o inimigo - "o outro", diriam os buraqueiros. O que o riso parece promover é antes a aproximação afetiva, ${ }^{7}$ ou talvez o riso queira mesmo matar apenas no nível simbólico, à medida que altera a identidade de quem ri. Ali, ri-se de si para se rir do outro (cf. Carneiro 2014). É preciso, portanto, conhecer aquele de quem se fala - é assim que de alguma forma se pode ser afetado pela experiência narrada. Voltaremos a este ponto. Vale aqui destacar nosso interesse em observar, a partir da análise dos causos, a conexão entre a vontade de rir ou bestar e a forma de conhecimento sobre "o povo parente dos Buracos", transmitida na circulação de palavras.

Em última análise, contar causo é posicionar-se na direção de uma teia móvel de relações, de tal maneira que o elo entre falantes e ouvintes é ora reforçado, ora enfraquecido. A teia estende-se entre o passado e o presente do acontecimento narrado, e com isto reatualiza e reconfigura as relações entre os seus. A variação da forma coletiva é tornada visível quando o povo é observado durante um intervalo de tempo suficiente para se testemunhar o surgimento de novas gerações e o desaparecimento das velhas. Está portanto condicionada não apenas às vinculações de interlocução numa determinada situação de prosa, mas também depende do conhecimento sobre outras relações entre pessoas e povos — conhecimento este que capacitará ou não o ouvinte a entender o que está sorrateiramente implicado em certas locuções.

Ao refletir sobre os causos, não podemos tratar apenas do acontecimento isolado, como um fato encerrado em uma narrativa. O causo não se encerra no ocorrido, ele envolve também as pessoas que o narram e os múltiplos rearranjos do ocorrido narrativizado. Para entendê-lo como prática de conhecimento, é importante percorrer, como fazem os narradores buraqueiros, os caminhos da circulação de versões que o constituem como evento narrativo, os caminhos que apresentam e promovem, ao longo de suas variações, qualidades de relações. A dimensão poética ou performativa dos causos, lembremos, reside afinal nesse movimento de criar e moldar relações ao mesmo tempo em que elas são narradas.

Na circulação de um causo, as versões podem ser contraditórias ou complementares, os níveis de detalhe variando em função de quem conta e de para quem se conta, como vimos. A contradição não é para eles exatamente um problema, ou melhor, ela é "o" problema: durante a escuta, o povo quer identificar a contradição entre duas versões de um mesmo causo. Ao contrastá-las, buscam perceber as ocultações ou adendos feitos pelo 
narrador, e especular sobre os motivos dessas diferenças. Um mesmo causo é necessariamente ouvido e contado inúmeras vezes e nunca se perde o interesse em um causo por já tê-lo ouvido antes. Ao contrário, quanto mais repetido o relato do acontecido, mais interessante ele é, e quanto mais repetido, mais interessante ele se torna, com mais detalhes e mais pessoas envolvidas na cadeia de relações que traçam a transmissão das informações.

As narrativas consideradas mais surpreendentes ou engraçadas permanecem em circulação durante anos ou décadas, mesmo que cada vez mais rarefeitas, mas ao serem recontadas, ganham novo vigor. Os "causos dos antigos" são acontecimentos narrativos deste porte. Eles podem ser referidos a casos variados - ciganos e onças, por exemplo, serão sempre bons personagens mas o casamento, posso atestar, é o tema que mais se perpetua através do tempo e mais se faz presente no circuito atual, instigando a continuação da conversa e fazendo rir os buraqueiros. Nos causos antigos, o assunto estende-se dos casamentos às suas implicações na reprodução e na transformação do povo.

O que melhor caracteriza os causos longos e detalhados, como aqueles dos antigos, é a situação em que geralmente eles são contados: o acontecimento da visita de parentes cuja moradia se localiza a uma distância que "o pé não alcança". Tais visitas ocorrem intensamente em determinadas épocas do ano, como o tempo das férias, "o tempo da política", "o tempo das folias". ${ }^{8}$ A "visita" é neste sentido um importante fator de coletivização, exemplo de situação na qual se contam e se escutam os causos dos antigos, abrindo a possibilidade de circulação de prosa e comida, engatando um processo a um só tempo narrativo e sociológico. Por este caminho, não parece se tratar de uma unidade, mas antes de um sistema de unificação.

Quando os que moram longe chegam em uma casa, o primeiro causo que se conta é forçosamente o do deslocamento que acaba de ser feito; ainda não entramos no reino dos antigos: o chegante-narrador conta quem foi encontrado durante a viagem, os percalços e as contingências da sorte que ajudaram ou não que se seguisse caminho. Esses assuntos poder-se-ia dizer que são ritualizados, uma vez que se repetem em todas as visitas, sempre ao se chegar e com as questões iniciadas pelos anfitriões. No momento certo, estes oferecem o de-comer que puxa mais prosa. Nos momentos que se seguem, a prosa é menos formalizada, podendo variar completamente de animação e duração em função da qualidade da interação entre aqueles que conversam. Estes causos em geral envolvem personagens já falecidos, muitas vezes o narrador não viveu a época daquilo que conta, mas conheceu quem viveu. Quando a experiência narrada é a do próprio narrador, tende a ganhar maior legitimidade (a não ser que o contador do causo, embora seja um dos antigos, seja também um notório "prosa ruim"). 
Ao estarem concernidos na teia pessoal e na paisagem ecológica evocadas pelos causos, narradores, narrados e ouvintes envolvem-se todos nos afetos narrados, cada qual em função da configuração familiar acionada a partir de si, até se chegar ao objeto da narrativa. O mapeamento feito por um mesmo causo segue então percursos diversos dependendo de quem escuta, isto é, em função do "povo" que escuta, pois cada qual tem seu "conhecimento" familiar e cada qual tem seus afetos prévios quanto àquele que é "falado". O bom narrador deve ser hábil para criar, em sua descrição das relações concernidas, uma aproximação dos sentimentos de quem o ouve, isto é, integrando posições, buscando contemplar o "tio" que sabe ser ele também "irmão", para falar como Zé de Ataíde.

Ao jogar com a relatividade das posições diante do ocorrido, o narrador dá ênfase ao traçado das relações que o situam em posição próxima à do ouvinte. Afinal, a condição de sujeito de enunciação detém um mapeamento provisório. Aquele que o escuta, ao recontar o causo ouvido, promoverá novos arranjos relacionais, resgatados a cada gesto de se narrar o ocorrido. Mesmo quando relaxados e entretidos, os presentes falantes avaliam o que dizer ou calar. Não como estratégia, mas como recurso tático usado para causar efeito nos outros. Se a produção de conhecimento dos buraqueiros, vimos, traduz-se parcialmente pela criação de intimidade, os efeitos de seu cálculo não são, como o termo nos sugeriria, elementos previstos por um jogo de estratégia, mas antes ofertas de confiança em um jogo de astúcia, um jeu de ruse. ${ }^{9}$

\section{O que é um povo?}

Se a constante reprodução do povo, necessária à manutenção de sua existência, consiste em casar, procriar e gerar filhos, ela só existe como movimento, ou seja, no processo contínuo de deslocamentos do território, de misturas de povos e pessoas. Estes, portanto, observados através das camadas de gerações passadas e das certezas de uniões futuras, são um e são muitos. Se percebermos o povo em sua duração, como fazem os causos, e não como um retrato instantâneo, ele constitui, como diriam Gilles Deleuze e Félix Guattari, uma "multiplicidade". ${ }^{10}$ Esta noção parece desvelar-se, por exemplo, na constante referência que os buraqueiros fazem a quem encontraram pelo caminho, informação sempre presente quando se está a contar causos. Quando dizem ter visto o "povo de Fulano", podem estar se referindo a uma ou a várias pessoas. No causo, a explicação sobre quem são as pessoas ou personagens - narradas serve-se da lógica da mistura entre "sangues" 
e "modos" para mostrar como, ao longo do tempo, uma personalidade foi se formando. Dizem, Fulano é assim porque o povo dele tudo é assim, As meninas de Bia é tudo igual à mãe delas, tudo sangue quente, O povo de Sinésio é comedor de farinha, O povo de Pulu tem uma conversinha mansa, O povo de Mazim é prosa ruim, na casa deles é só café corajoso, o café que vem sozinho, sem o de-comer para acompanhar.

Quando o assunto são os gaúchos, a diferença parece irredutível, gaúcho só vive é de porta fechada, recebe você da porta para fora. Os "gaúchos" são famílias vindas do interior do Paraná ou do Rio Grande do Sul no final dos anos 70, subsidiadas pelo governo militar para plantação de grandes monoculturas. Eles moram na sede do município de Chapada Gaúcha-MG, onde se situa o povo dos Buracos. Este, ao falar dos "gaúchos" torna-se "o povo mineiro", juntando-se a todos os povos das Gerais em oposição aos primeiros. Gaúchos nunca são protagonistas dos causos, talvez porque seja difícil traçar a rede de relações reunindo narradores, narrados e ouvintes necessária ao causo, afinal nunca houve um gaúcho casado com uma buraqueira.

O sistema dos gaúchos é diferente do dos mineiros. E o que é "sistema"? - pergunto. É o modo de comer, de conversar, respondem-me, Aquele povo é brabinho, caipira, nem sabe conversar; Fulana tem uma prosinha mansa, parece até que tem medo de gente; Fulano é prosa ruim, não come na casa de ninguém! Aqueles povo de Cicrana é tudo besta, só come carne, não quer arroz e feijão, não; Gaúcho é prosa ruim, não come de junto dos mineiros! Estas são algumas das frases recorrentes nas avaliações sobre a moral e a qualidade das relações buraqueiras; assim elas vão aplicando esse traço importante nas formas de classificação do povo dos Buracos sobre seu próprio modo de vida. Baseando-se nos modos de comer e de conversar "dos outros" e de si mesmos, os buraqueiros dão densidade às descrições daqueles que narram, ou seja, de seus parentes, de seu povo, de sua gente.

O cotidiano da terra buraqueira é marcado por deslocamentos internos observáveis facilmente por alguém que se mantém fixo em uma única casa, onde a entrada e a saída de gente variada ao longo do dia traz notícia sobre "o rumo do povo". Diariamente, distâncias maiores ou menores são percorridas pelas pessoas, seja por necessidade ou por afeto; seja para pedir um prato de milho, uma casca de pau ou para bestar. As ocasiões podem render uma conversa apressada, em pé ao pé da porta; um gole de café e uma fofoca (causo envolvendo intimidade e segredo); um cochilo esticado na esteira após a prosa; um aceite para puxar o almoço, e daí por diante. É nas casas que o povo conversa.

Não há ponto central na configuração do espaço dos Buracos, seja uma praça ou o que o valha onde os buraqueiros pensem em se encontrar 
cotidianamente. Os encontros são espalhados e muitas vezes casuais, as conversas que ocorrem nesses momentos são repetidas então de forma a tornar "público" um conhecimento de interesse geral. E, nos Buracos, há poucos assuntos, ou nenhum, que não sejam de interesse geral. A existência de duas escolas e dois campos de futebol, cada um em uma extremidade do grande cânion, repercute a divisão de dois agrupamentos familiares amplos. Na vizinhança do "povo do Calengue", herdeiros de João Branco, o primeiro proprietário, a escola e o campo são melhores do que na outra, e situam-se na área de mais fácil acesso à estrada que leva à Chapada Gaúcha. Recentemente houve alguns casamentos entre gente desses dois núcleos familiares (subdivididos em outros povos/famílias), e assim cresceu a intensidade de circulação entre ambos, tornando menos nítida a distância que os separa quando analisamos as diferentes versões de um causo. A mãe moradora do Calengue cuja filha se casou com um rapaz de Três Passagens será sempre portadora de notícia de lá, estando mais inteirada dos assuntos de longe do que dos da vizinhança geográfica.

Há deslocamentos rotineiros também entre os Buracos e a cidade Chapada Gaúcha, a "vila", onde fica o posto de saúde, maior e mais legítimo motivo para se ir até a cidade - não raro, mulheres e moças, querendo livrar-se da suspeita de maridos e pais ciumentos, inventam um problema de saúde para "subir a serra" rumo ao posto médico. O povo idoso ao menos uma vez por mês sobe a serra para pegar a aposentadoria e fazer "a feira do mês", período em que também as mães sobem para sacar o dinheiro do Bolsa Família. Há ainda os jovens que não perdem uma festa na "rua", e as moças que trabalham durante a semana em casa de família, em geral dos gaúchos chapadenses, e nos domingos descem aos Buracos. Após o estabelecimento do Conselho Tutelar na sede municipal, os jovens passaram a cursar obrigatoriamente o Ensino Médio, de modo que, nas novas gerações dos Buracos, todos os jovens passam pela experiência de morar na vila.

Os rapazes, em sua maioria maciça, não completam o curso secundário, voltando logo a morar nos Buracos, onde a maioria deles está solteiro. As moças, ao contrário, em geral conseguem se formar e acabam por se estabelecer em Chapada. Outras não se formam e vão "caçar rumo" em Brasília, onde muitos buraqueiros se estabelecem, outros tantos ficam uns meses e depois retornam, repetindo em maior escala o movimento que descrevi na rotina das casas. A intensidade da comunicação entre as três localidades faz-se explícita ao percebermos, por exemplo, que todas as famílias buraqueiras ou bem possuem uma casa em Chapada ou têm vínculos com um "parente chegado" sempre disposto a lhes oferecer "pouso" por ali — por dois ou três dias, "resolvendo uns trens na vila", ou mesmo por um período mais longo. 
Similarmente, em Brasília, especialmente em Ceilândia, qualquer buraqueiro encontrará um pouso familiar para passar uma semana ou mesmo um mês, dependendo da urgência do caso. Desta forma, o território existencial dos buraqueiros se move, conforme a circulação de palavras e de pessoas, seja nas estradas que levam para longe os parentes, na serra que liga a vila e a roça, ou nos telefonemas e contatos virtuais rotineiros entre os que foram e os que ficaram.

Hoje, morando no Rio de Janeiro, costumo ligar para Ceilândia-DF, onde atualmente moram buraqueiros próximos a mim; recebo então informações sobre todo o povo dos Buracos e, em contrapartida, sei que basta passar uma informação pelo telefone e todos nos Buracos terão conhecimento, prolongando o assunto narrado por mim quando de minha futura presença ali. Atualmente, quando retorno aos Buracos para revê-los, os buraqueiros já me encontram informados sobre as notícias que transmiti ao povo. Assim, a palavra "povo" pode ser uma pessoa ou um bocado delas, um parente sempre "puxa" os seus. Sabe-se que, se não estiverem juntos, brevemente irão se encontrar ou, se distantes, conversarão por telefonemas e recados. Independente da unidade pessoal, um ou muitos, referir-se ao povo é referir-se a uma articulação entre um grupo de casas e as notícias que saem dali, isto é, a uma certa circulação de prosa e comida.

Mas se este povo se caracteriza por um constante espraiamento do território, de incorporação do exterior, a antiga fazenda dos Buracos mantém-se como ponto de força centrípeta, "puxando" o interesse dos buraqueiros, assim como a paisagem atual puxa para perto deles a presença dos antigos, "o povo de primeiro". A terra e sua paisagem e o tempo dos antigos assumem para os buraqueiros a forma de um elo nunca perdido, sob o risco de se perder da própria família. Nisto reside, me parece, um trabalho de unificação constante inerente às formas de dispersão e circulação do povo. Cabe perceber que, para além do movimento de aproximação entre narradores, narrados e ouvintes, há um movimento importante, paralelo e oposto de distanciamento. Este se produz também pela explicitação da cadeia de relações tecida na narrativa, uma vez que ela conecta mas também explicita a distância entre as pessoas conectadas.

É na tensão, no risco de desequilíbrio indicado pelo riso, que esta "boa distância" parece merecer ser criada. É sobretudo recorrendo ao humor, presente em toda "boa prosa", que o distanciamento se cria de modo interessante, pois a rigor o povo acha graça sempre "dos outros". Gente besta!, dizem às gargalhadas. E como se percebem imediatamente ligados aos narrados de quem riem, subentende-se que também riem de si, fazendo do riso um movimento de reflexividade ${ }^{11}$ Mesmo quando o próprio nar- 
rador é o protagonista do causo, ele mantém em relação ao que conta um distanciamento obtido como o efeito do engraçado, da galhofa de si. Neste sentido, há um equilíbrio instável no qual todo narrador deve se manter ao se relacionar com narrados e ouvintes. Afinal, se o objetivo de todo contador de causo é promover a risada dos que o escutam - "animar o povo", "entreter" - há sempre, por outro lado, o risco de calcular mal, e da graça parecer desrespeito, ofensa.

Como conta Bailey (1971:13) sobre os habitantes de uma pequena aldeia nos Alpes franceses, o "uso tático das pistas que comunicam uma impressão e administram uma situação [...] gera uma formidável sofisticação e complexidade" na conversa entre aqueles que são "mestres da mesma linguagem". Gifts também carregam poisons, escreve o autor, para mostrar em seguida o poder de eloquência do laconismo entre aldeões franceses. A palavra, nos Buracos assim como na aldeia de Bailey, é uma dádiva e um veneno, tão valorizada quanto temida. Uma palavra mal dita encerra a prosa de forma abrupta e constrangedora e pode ser, no dizer buraqueiro, "o mesmo que dar veneno": os falantes entram em conflito e disto eventualmente decorre a suspensão definitiva de suas trocas verbais.

Às vezes, o ardil é uma ofensa sutil - por exemplo, desdizer um causo contado - e seu efeito dependerá da tática do outro. Fazer a "prosa render" é uma questão de manter o "povo unido", "povo forte", mas se esta formulação parece destacar o caráter coletivizador da prosa, é importante que não se deixe de lado seu forte potencial de ruptura. O que ora chamei de equilíbrio instável do narrador baseia-se na certeza de que o perigo de uma palavra seja mal dita. Prosear não é necessariamente conectar, vimos, e a paz entre falantes muitas vezes requer constantemente um silêncio eloquente, como formulou Bailey. Como diz o dizer nos Buracos, se a palavra é de prata, o silêncio é de ouro. Por outro lado, como vimos, é preciso conversar, sempre.

Graziele Dainese (2014) encontrou em outra localidade de Minas Gerais um "modo de prosa" em alguns aspectos muito similar ao dos buraqueiros e mostrou como o silêncio ali pode ser mais perigoso do que a prosa. De um lado, a ausência de palavras é considerada "pouco causo", um grave gesto de ofensa, indicador de indiferença. No momento de um encontro, o silêncio sinaliza ruídos na relação; a valorização moral da união e a harmonia entre as pessoas exprimem-se no valor dado à conversa. Saber conversar é, sobretudo, saber conviver, explica a autora. De outro lado, a imposição da conversa não corresponde a um falar desmesurado. Como notou uma informante de Dainese citada por esta, "tem gente que gosta de falar, quando encontrar gente assim tem que cuidar pra não falar também" [grifos meus]. Ela orientava a pesquisadora sobre a necessária atenção aos rumos que a 
conversa poderia assumir na convivência de vizinhança, e lhe ensinava que a criação de intimidade requer enorme cuidado, quanto mais próximo mais perigoso é o outro.

Em suma, é preciso a todo custo evitar "falação", mas sem que isto retire da prosa o interesse de seus interlocutores. Como dizem os buraqueiros, é bom quando a prosa rende. ${ }^{12}$ Para evitar palavras mal ditas, há todo um repertório temático que pode ser sintetizado por um conceito polifônico: o "sangue". Incluem-se aí desde doenças e heranças do corpo até doenças e heranças da alma, passando por temas como o amor, a loucura e - como possível e medonho sinal associado a estes - o feitiço. Se o sangue conecta todos esses assuntos é justamente porque, ao acionar um determinado significado, pode deixar outros em aberto, oferecendo ao ouvinte sua própria condição de cálculo. Fala-se sobre todas as possibilidades de associação ao mesmo tempo, sobre muitas coisas como se estivesse dizendo apenas uma. Como costumamos colocar, joga-se com o sentido do que se diz. Ou, como dizem os buraqueiros, fica-se "no cálculo". Só captura o sentido aquele que tem "conhecimento", isto é, que conhece as relações pessoais implicadas e não verbalizadas na cadeia narrativa do causo.

Circulando sistematicamente entre as casas mais próximas e mais distantes dos Buracos, é fácil observar que as versões de um mesmo causo variam conforme a configuração das vizinhanças buraqueiras: aquelas que circulam entre casas próximas assemelham-se entre si; conforme vamos nos afastando para casas mais distantes, as versões vão se diferenciando umas das outras. As variações das versões de um causo acompanham, portanto, a composição de um território do parentesco que não se define exclusivamente em função de uma extensão geográfica, e o que vale primordialmente é a intensidade da circulação de conversas (cf. Comerford 2003). Assim, a forma do "causo", como a do "povo", vincula-se aos seus contextos de circulação, ao constante fazer, desfazer e refazer de relações que tais contextos geram ou viabilizam. A partir dos causos que se ouvem e se contam, cada qual buscando sua tática de fazer divertir, uns puxando outros, a "gente" cria "intimidade", ganha "costume", "conhecimento" - as pessoas tornam-se "chegadas".

"Contar causos" é fazer a "prosa render", o que é a um só tempo índice e motor de boas relações. Contar causo é "formar um povo". Quando se ouve da casa vizinha a barulhada da gente ao lado, comenta-se, O povo está barulhando, o trem está animado. O comentário não raro traz um sentimento de ciúme, não verbalizado mas explicitado em cobranças, como, Vocês foram na casa de Fulano e nem apareceram por aqui! Não é à toa que, "no tempo da política", a rotina de campanha dos candidatos consiste em fazer visitas às casas do "povo da roça", isto é, os diversos "povos" que habitam 
o município. Dentro de casa, local por excelência da prosa prolongada, é neste sentido um espaço público.

\section{Falas que fazem formas}

Em certo sentido, a noção buraqueira de "causo" aproxima-se daquilo que se imaginou a respeito de uma antropologia da experiência: "tem uma dimensão temporal explícita na medida em que nós atravessamos [go through] e passamos por [live through] uma experiência, que então se torna autorreferente no gesto de contar [in the telling]" (Bruner 1986:7). Isto não parece significar que se trate aqui de um conhecimento imaginado pelos buraqueiros como subjetivo, mas sim "pessoal", isto é, uma atividade prática de criação contínua de perspectivas, tendendo à perspectiva pessoal de quem conta. A história "pessoal" envolve "um pessoal", fazendo distinções e identificações incluindo-se, excluindo-se — de pessoas e povos.

O paralelo entre as narrativas do causo e da escrita etnográfica sustenta-se nas diferentes formas com que uma e outra pretendem descrever, cada qual à sua maneira, a forma coletiva apreendida de suas relações pessoais, e mesmo íntimas, estabelecidas na experiência da conversa, seja no campo etnográfico, seja nas cozinhas dos Buracos. Nos dois casos - o dos causos e o dos relatos etnográficos - a forma coletiva é apreendida e reconfigurada a partir dos conjuntos de relações tecidas em um tempo e espaço determinados, a partir de uma perspectiva pessoal. Um sujeito com "muito conhecimento" é um "sujeito experiente", que "caminhou por esse mundão tudo", que "conheceu todo tipo de gente".

O conjunto destas expressões parece revelar uma associação suposta entre o conhecimento, a experiência de deslocamento e a produção de relações pessoais. Por outro lado, para aprender, a pessoa precisa ter "influência", "invocação", "incutimento", tal como um bom folião quando criança, invocado com a viola, tem muita influência, aprendeu a tocar como ninguém. A ideia, presente nas avaliações buraqueiras, de que um sujeito com muito "conhecimento" é um sujeito influente, que tem muitas relações pessoais, permite-nos uma articulação interessante entre estes dois aspectos da produção de conhecimento nos Buracos. De um lado, a dimensão atrativa, afetiva, do conhecimento associada à experiência de deslocamento - tal como os parentes chegados "puxam" uns aos outros. De outro, um acúmulo de relações pessoais necessário à habilidade retórica para ganhar perspectivas, ter autoridade, "respeito".

O conhecimento produzido nos Buracos pela circulação de causos, vimos, depende das coordenadas que situam o provisório narrador, bem 
como seus narrados e ouvintes, em um determinado mapa, compartilhado e reconhecido por todos, o que aproxima os interlocutores sem no entanto apagar a distância entre eles. A verdade que os ouvintes buscam atestar em um causo é avaliada em função de sua própria experiência no fluxo contínuo de configurações relacionais, contrastando-a com o mapa oferecido pelo narrador para eventualmente discordar dele silenciosamente e, noutra casa, contar o causo de acordo com sua discordância. O esforço consiste, deste modo, em criar uma forma narrativa que oriente as perspectivas variáveis dos interlocutores rumo ao reconhecimento de uma mesma formação coletiva. Lembre-se que está, entretanto, em constante transformação.

Esta relação singular entre forma narrativa e verdade aponta para uma articulação específica entre conhecimento e poder, o que - no paralelo traçado aqui - repercute na própria maneira com que concebemos nossa "autoridade etnográfica". Mais uma vez, é pelo viés da escrita que o problema político se coloca. É o que sugere Marilyn Strathern ao explicar sua insistência na retórica como instrumento de análise, como capacidade de deslocar-se das formas dadas, de uma estética específica.

[...] as coisas que vivem na cultura — ou na vida — vivem porque elas têm uma forma particular, e elas persuadem porque tomam uma forma particular [...] $\mathrm{X}$ e Y puseram tal questão de tal modo, mas que há outras coisas a se pensar e, portanto, mudemos a forma pela qual eles estão pensando. [...] Meus argumentos são sempre em benefício do argumento (Strathern1999:167).

Toda análise social objetifica (cada qual a seu modo) as formas coletivas que se observam no mundo, explica Strathern. A retórica seria então uma operação analítica através da qual as formas persuasivas, tidas como dadas em determinada cultura, são deslocadas, ou deformadas, em benefício da criação de outras formas possíveis, outras formas de composição do que se observa. Strathern propõe, como abordagem antropológica e como objetivo de trabalho, mudar a maneira com que as coisas se assumem como dadas. A dinâmica da conversa nos Buracos, parece-me, opera um deslocamento similar, sendo ela mesma matriz das formas lábeis assumidas como delimitadoras da vida coletiva.

Assim, nosso objeto de análise, o causo, apresenta-se como operação coletivizadora tanto no nível das relações pessoais (o povo) quanto da ordem discursiva (a prosa em suas variadas formas). Como vimos, o povo, esta formação coletiva constituída no tempo e no espaço, está em variação contínua se a observarmos durante determinado intervalo de tempo, mas a cada instante da experiência, a forma observada se assume como experiência total. Ao buscar colapsar as formas do povo e do causo, o fato sociológico 
e o discursivo, reforçamos a ideia de uma formação coletiva engendrada por determinada circulação de prosa. Neste ponto, cabe perguntar: como deslocar nossa forma de assumir as coletividades a partir do contraste com o pensamento produzido pelo causo buraqueiro?

\section{O causo da televisão de Januária}

A figura do "contador de causo" é recorrente na rede de ensino municipal de Chapada Gaúcha-MG. Como parte de suas atividades pedagógicas, as professoras municipais promovem sessões de "contação de estórias" para seus alunos, chamando para conversar na sala de aula "o povo velho da roça", o povo que "sabe contar" os causos antigos. Esta mesma atividade é promovida pelas professoras durante a Festa do Encontro dos Povos do Grande Sertão, realizada por ONGs da região e pelo governo municipal. Na ocasião, o povo de todo o município de Chapada se reúne na vila junto ao povo de fora, gente de Montes Claros, Brasília, São Paulo e mesmo Rio de Janeiro. Dona Bibi, a senhora que conta o causo da televisão de Januária, é uma dessas figuras que se tornaram lendárias nos contextos como os da escola e da "Festa do Encontro".

Cerca de um ano após a conclusão de minha tese de doutorado sobre o povo dos Buracos, retornei ao campo para acompanhar uma oficina de documentários dirigida a jovens e adultos, patrocinada por uma ONG criada por professoras municipais de Chapada. Dona Bibi foi uma das entrevistadas pela turma, cujo exercício consistia em produzir um documentário curta sobre "contadores de causo", termo empregado e repetido por nós e por todos os chapadenses envolvidos na oficina. A ideia era registrar os causos dentro da casa dos narradores, buscando reproduzir uma situação de visita, mas o plano não deu certo, os narradores não se sentiram anfitriões de nossa equipe de gravação. Era de se esperar. Ao invés da visita desinteressada e sem hora para terminar, chegávamos com hora marcada para ir embora. E pelo desajeito de receber de repente tanta gente desconhecida, restava aos narradores acomodar os chegantes em pé, assistindo à prosa desconfortavelmente. De nossa parte, frustrávamo-nos com o laconismo dos proseadores. O primeiro causo interessante que conseguimos gravar em nossa jornada de entrevistas foi o narrado por Dona Bibi, mas isto depois de uma sequência de equívocos que impôs a todos os interlocutores um esforço de compreensão para além do previsto. A seguir transcrevo parte do diálogo registrado pela câmera.

A senhora tem algum causo de festa junina?, perguntou-lhe Ricardo.

Ah! É o que mais tem!..., reagiu, dando partida em sua memória. É só estória antiga, ia de a pé... a Festa de Santo Antônio da Serra, em junho, 
mês de Santo Antônio, São Pedro e São João. Era bom demais, ia no carro de boi... Fogueira... Tudo comadre... Hoje, faz fogueira, mas nem pula, hoje é quentão, no meu tempo assava batata! Era bom o tempo de primeiro! Hoje, não. De primeiro, sim. O carro de boi, a viagem, a comida, a bebida, a festa, os parentes, tudo era mais unido, mais divertido, tudo era comadre, compadre... Hoje, não. Eu até perdi a influência de ir na Festa da Serra. Antes era comadre, compadre, hoje não! Uns parentes mais bonitos nem querem apresentar ser parente da gente. Nem diz que é parente, é conhecido!

A esta altura, intervém o professor Ricardo, um amigo carioca que eu convidara para conduzir a oficina. A intervenção revelava certa ansiedade, a realização de um documentário com os contadores de causo previa, afinal, que daquela conversa nascesse um trecho editável, algo "estruturado". Queríamos identificar uma ordenação narrativa e não encontrávamos. Bibi ri como que para preencher o espaço, pois não sabia o que responder, fica reticente. Ricardo insiste, Mas eu queria mesmo era ouvir um causo! Um causo, um causo de festa junina... Bibi repara na insistência de seu entrevistador e faz silêncio. Por certo está percebendo o mal-entendido, a falha de comunicação, pois em seguida diz, reticente,

Ah sim, festa junina! Você quer dizer assim, a nossa, né?...

Sim! Uma estória boa!

Dona Bibi ri. Ahaha! Com a risada, ela parece tomar o tempo necessário para refletir sobre o que responder. No que consistiria a relação estabelecida entre nós e Bibi diante da câmera? Como construir a aproximação necessária entre narradora, narrados e ouvintes? Qual seria o interesse da equipe de gravação naquela prosa? O rumo da prosa ficara incerto. Bibi sabia que "o povo da cidade" gosta de conversar sobre "o tempo de primeiro", foi isto que ela quis oferecer, mas nós não parecíamos satisfeitos. Bibi retoma o fôlego e tenta entender Ricardo,

Estou contando, insiste ela, a gente dançava roda, batuque...

E então retoma sua linha de argumentação anterior: o tempo de primeiro, a dança, as cantigas de roda, o batuque do tempo de primeiro.

Você quer saber, assim, festa nossa, né?, averigua.

Ricardo busca outra forma de perguntar,

Tem um acontecimento, uma coisa que tenha acontecido e que a senhora não tenha esquecido?

Novo silêncio se faz e em seguida mais perguntas de Bibi, que outra vez fica muda uns instantes para só então retomar a fala devagar, agora refletindo sobre sua forma de abordar o tema do passado.

Algumas coisas... Já passou. Quando a gente era nova, moça, menina, a gente nem lembra mais, sabe. Porque a batalha da gente é muito complicada... 
Pra lutar é essa filharada, a mão impede a gente a cabeça. Muitas coisas... Algumas eu lembro, outras nem lembro mais... Porque hoje ninguém dá valor nisso... Essas estórias velhas, esses passados... Argh! É estória de gente besta! De gente velho! Ninguém dá valor na gente mais. Ainda a gente dá graças a Deus quando vem um de fora que quer saber... Renova, sabe! Renova as estórias velhas! Mas hoje ninguém quer saber de estória velha mais não. Por isso muitas coisas até saem do cérebro da gente [...] Ah! Eu gosto de contar mais é estória, de piada do tempo velho, de primeiro... E aconteceu comigo também! Porque o que aconteceu comigo... Vai ficar por estória de meus netos, sabe. Porque naquele tempo ninguém conhecia televisão... Eu mesma fui conhecer depois... [...] Eu já contei a estória que aconteceu comigo? Que passou comigo? Em Januária? Da televisão em Januária?

Dona Bibi espera a reação do interlocutor.

Conta pra gente, diz ele.

Ela então inicia o mapeamento das relações entre narradora, as pessoas e as paisagens narradas. Sem encontrar uma cadeia pessoal ligando-as aos interlocutores, estes certamente se identificariam com a paisagem da cidade, que para Bibi era, naquela época, Januária. No tempo em que o povo da roça, como Bibi, nunca havia visto televisão, Januária representava o "povo da cidade". Hoje, o contato com gente das metrópoles brasileiras se ampliou, isto é, o povo da cidade se ampliou, formando uma rede capaz de acessar o povo do Rio de Janeiro à patroa da irmã de Bibi. Após o mapeamento inclusivo típico dos causos dos antigos, como vimos - Bibi prossegue. Em Januária, eu tinha o quê? Uns 24 anos... Não conhecia Januária, não. Foi a primeira vez que eu fui, levei minha menina doente. Quando cheguei lá (minha irmã trabalhava em Januária), fiquei na casa da patroa dela. Quando cheguei lá, deitei a minha menina amortecida... Eu cheguei, não sabia o que era televisão... Cheguei, aquela televisãozona grande assim na parede. Eu achei que era uma janela! Estou lá, sentada, meio de lado. E a patroa (chamava Amparo) ligada na televisão. E eu de lado... Mas o quê?... Não aguentei, não! Ficava curiosa, né! Não aguentei, não! Aquele movimento! Aí não aguentei, não! Aí levantei e fui lá na cozinha. Falei pra minha irmã, Tonha,

Esse povo de Januária é assim?

Assim como?

Povo atencioso, cheguei e todo mundo veio visitar minha menina! Mas gostei! E ela deu risada

Você perguntou isso pra [patroa] Amparo? Ahaha! Ôh! Isso é televisão, minha irmã!

Minha irmã disse, e eu disse, É não, Tonha, o povo me olhou pela janela! É não, é televisão! 
Meu Deus do céu! Que eu voltei, que eu fui curiar, aquelas mulherzonas tudo bonita! Mas conversava comigo assim. Sabe? Eu achei, menino, que eles estavam me visitando pela janela... Ah! Mas isso... Vai ficar por estória. E aconteceu comigo! E isso vai ficar pros meus netos, pros netos dos meus netos. Vão dizer, A bisa de meu pai, aconteceu isso com ela... Mas estória é realidade! Estória também é realidade!

\section{Estória também é realidade}

Piada e estória, diferentes do causo, não necessariamente precisam "ter acontecido de verdade", explica-nos Bibi, por outro lado, podem sim ter acontecido, Aconteceu comigo!, enfatiza. Estória é realidade, também é realidade. O que difere então a estória do causo? O que significa dizer que um causo "vai ficar por estória"? Estória e piada, conforme a formulação de Bibi, parecem ser sinônimos. O causo, por outro lado, guardaria a necessária relação com um acontecimento real, uma experiência pessoal estendida, como vimos, à cadeia de transmissão do causo, ligando pessoas pela troca de palavras. Quem contará no futuro, portanto, serão por suposto os descendentes diretos, aqueles com quem mais se conversa, Vai ficar pros meus netos, pros netos dos meus netos, diz Bibi, Vão dizer, A bisa de meu pai, aconteceu isso com ela. A necessária articulação, efetuada pelo causo de Bibi, entre realidade e relacionalidade, não só no que se conta, mas no que é produzido no contar, implica um determinado modo de relação - de comer e de conversar - implica animação, barulhada, risada.

Como bem descreveu John Comerford (2012), "parente é assunto". Narrando uma entrevista dada por um senhor de idade do Alto Paranaíba, onde o autor iniciava uma pesquisa de campo, ele apresenta o argumento do senhor que lamenta a "falta de assunto" das novas gerações. Por falta de interesse e conhecimento sobre as relações familiares, reduzem-se o tempo e a qualidade da prosa a uma função meramente informativa, mostra Comerford a partir do argumento do entrevistado. A forma de intensificação dos vínculos pessoais - própria à circulação do causo e desvinculada da função informativa, como vimos - é explicitada também na reclamação de Bibi sobre a mudança dos hábitos de prosa, Não é mais parente, é conhecido! Sem a relação de interlocução, os causos até saem do cérebro da gente, fala Bibi, É coisa de gente besta, dizem. No deslocamento entre causo e estória, o que se perde são as relações. Antes era tudo parente, comadre, compadre. Hoje é só conhecido, diz Bibi. Com os "conhecidos", não se tem muito "conhecimento", não se têm relações importantes, a prosa não rende. 
Assim, quando a equipe de gravação pediu a ela que contasse um causo, Bibi começou puxando pelos causos dos antigos, afinal são estes que os turistas gostam de ouvir, ela sabe. Não conseguiu narrar um acontecimento muito elaborado, como os causos dos antigos que mencionei acima, mesmo assim eram "causos dos antigos". Como afirmei inicialmente, o termo "causo" não corresponde a uma forma narrativa singular, é antes uma categoria aplicada a praticamente qualquer situação de conversa. Bibi ainda não havia puxado pela memória um "causo bom", engraçado. Nossa prosa não estava rendendo muito. Por outro lado, o termo "causo" usado por nós certamente não nos ajudou. Depois dessa ocasião, em conversa com a secretária Municipal de Educação e Cultura de Chapada, ficamos sabendo que, nos eventos pedagógicos para os quais os contadores de causo são chamados, não lhes são pedidos "causos", mas sim "estórias", esta é a expressão correta, ensinou-nos a secretária.

Havíamo-nos equivocado, mas é curioso que o equívoco tenha sido não um desentendimento sobre o uso do termo causo, e sim sobre a circunstância em que nos encontrávamos. Estória também é realidade, explicou Bibi. Ela percebeu que queríamos não um causo, mas uma estória, dessas cuja graça independe das relações entre quem ouve e quem narra, dessas que ela conta aos estudantes e aos turistas. Isto explica por que nem as professoras que ajudaram a organizar a oficina nem os alunos da oficina perceberam o equívoco do termo enquanto fazíamos as entrevistas. Sim, um "bom causo" era corretamente o que queríamos ouvir, mas para isso seria preciso criar aproximação, animar, puxar prosa. Nossas perguntas do tipo jornalístico não criavam associações, nem entre assuntos nem entre pessoas, de modo que os causos não eram puxados da memória. Depois que o causo da televisão de Januária foi narrado para a câmera, mostramos o registro às professoras, que comentaram já terem ouvido aquele causo, algumas até em versões melhores, disseram-nos, notando a tensão disfarçada de Bibi.

Porque hoje ninguém dá valor nisso... Essas estórias velhas, esses passados... Argh! É estória de gente besta! De gente velho! Ninguém dá valor na gente mais... Quando reclama que os jovens consideram sua prosa "estória velha", Bibi aponta para a falta do que considera serem boas relações, relações exemplares, como as que existem entre comadres e compadres, isto é, parentes especiais, "gente chegada". Hoje, os meninos só no pé da televisão, não se interessam mais pela prosa de Bibi, reclama ela. Talvez o lamento esteja carregado de certa dramaticidade, pois é fácil observar que crianças, os jovens e outros de qualquer idade, da roça ou da cidade de Chapada, continuam tendo seus momentos de prosa prazerosa com os antigos, mesmo que certamente com interesses variáveis de acordo com o assunto e as pessoas falantes. 
De todo jeito, é importante ouvir o lamento de Bibi, ele é eloquente, aponta para um provável enfraquecimento desses modos de prosa. Esta minha impressão, que não soe algo como um pessimismo sentimental, para falar como Sahlins, baseia-se no contato que venho mantendo há oito anos com o povo dos Buracos, hoje com visitas esporádicas. Atualmente, em qualquer casa buraqueira, durante as noites, raramente "o povo" se reúne na cozinha para uma prosa de três ou quatro horas, como faziam no ano em que os conheci. Agora a conversa da noite se dá frequentemente em frente à $T V$, e é entrecortada por momentos de apatia nos quais se presta atenção à telinha animada. Como formulou Zé de Ataíde, Televisão é o trem mais sem assunto que já inventaram!

Estávamos sem assunto com Bibi. Foi então que Ricardo, na busca por comunicação, formulou, Tem um acontecimento, uma coisa que tenha acontecido e que a senhora não tenha esquecido? Foi neste momento que Bibi parece ter tido um insight, a imagem mostra seu olhar pensativo enquanto alterna o silêncio com algumas perguntas. E então começa devagar sua reflexão sobre os gêneros narrativos: estória e piada, de um lado, causo do outro. A mudança no regime de prosa, identificada por Bibi a partir de nossa conversa truncada, consiste em uma transformação da forma narrativa do causo; ele deixa de ser "puxado" pelas relações entre interlocutores e narrados, e passam a parecer piada ou estória, isto é, narrativas encerradas em si mesmas, que não têm, por este motivo, o intuito de mostrar as evidências da verdade do que se conta (isto é, o mapeamento inclusivo entre narradores, narrados e ouvintes).

Como vimos, a intensidade da prosa é reflexo de aliança, um código de ordem política. Manelão da Matão, outro entrevistado nosso, era um "homem simples", um "homem da roça", mas havia "subido na política" graças aos seus conhecimentos junto aos gaúchos. Hoje tem o porte de um homem poderoso e a simpatia da gente da roça. Após o causo de Dona Bibi, a experiência com Da Matão foi bem diferente. Ele percebeu logo o que queríamos e, sem recusar a entrevista, explicou-nos que, para a equipe ouvir um causo bem contado, o melhor seria sentar-se à noite ao pé da fogueira, todos aquecidos com cachaça e animação. Como nossa produção não podia contar com os custos e o tempo necessário a esta operação, tivemos que nos contentar com um bocado de causos mal esclarecidos, pouco espontâneos.

Dona Bibi, entretanto, salvou-nos com uma bela narrativa depois de ter entendido nosso equívoco. Pensando nele, lembrou-se do causo da 
televisão, puxou da memória o assunto que a presença da câmera e dos jovens puxavam: a mudança dos modos de vida nas últimas décadas. Por certo lembrou-se também da patroa da cidade, dona da televisão, que por algum caminho certamente se conectava conosco, a equipe de gravação da cidade. Éramos todos "povo da cidade", este povo diante de quem hoje Bibi se lamenta, Ainda a gente dá graças a Deus quando vem um de fora que quer saber... Renova, sabe! Renova as estórias velhas! Bibi aproveita a oportunidade do registro audiovisual para dar sua resposta às moças que riem dela desrespeitosamente, Se não fosse as mulheres velhas, não existiam as moças novas. Este verso de uma canção de folia nos foi cantado por Bibi quando um dos alunos lembrou de sua fama de soltadora de versos que vinha junto à de contadora de causo e de "remedeira". Este conjunto de atributos rendia a Bibi certa notoriedade entre a "gente de fora", interessada na "cultura sertaneja".

Ela faz uso de nossa escuta e prossegue sua reflexão como fazem os bons proseadores, gozando novamente de si, Eu sou velha!, disse ela já ao final da entrevista, Então eu falo igual ao dizer do povo velho. Que o povo velho falava tudo errado, né. Mas eu até hoje falo, porque hoje modelou tudo. Os dizeres do meu tempo, hoje, se falar, fala é tipo assim... É uma piada... Mas o povo velho falava assim, Não, puta velha não importa! Ahahahá! Hoje fala assim: por ser velha. Né? E o povo, Ah, "pur-tá" [por estar] velha não importa. Ahahahá! Pois eu, pu-ta velha não importo, não! Ahahá!

Como afirmou Clastres (2003 [1974]:148), "nós não somos índios, mas talvez encontremos, ao escutar seus mitos, alguma razão para nos alegrarmos com eles". Os causos - dizem os buraqueiros - ensinam sobre o povo. Ao mesmo tempo este riso só eclode se nós ouvintes formos capazes de imaginar o protagonista a ponto de coincidirmos nossas experiências, isto é, se formos capazes de "conhecê-lo" no sentido buraqueiro. Para isto, a narrativa encadeia relações que nos envolvem.

Voltando às questões de fundo deste artigo: que espécie de conhecimento é conceituado pelo causo? Que forma de pensamento ele efetua sobre aquele povo? O que é um causo, afinal? Como vimos, não se tratou de buscar delimitações para esta forma narrativa, pois ela pode consistir tanto em frases curtas quanto em preleções de horas. Sua especificidade encontra-se em práticas criativas vinculadas à sorte do encontro, a situações irredutivelmente contingentes. Narrar um causo é buscar efeitos de estabilização do encontro e da rede de relações que ele engaja. Portar a voz é adquirir assim uma espécie de controle transitório.

Não se trata apenas de notar a aproximação entre este modo de prática discursiva e a construção de sua autoria e autoridade etnográfica — tal como 
colocado pelos pós-modernos sobre o problema ético e político (e também moral, conforme Sahlins 1997) implicado nas relações de representação antropológica. Creio que o mais instigante nesta análise está na dimensão cômica que essas relações produzem. Parece-me ser este um caminho promissor para a continuação do argumento apresentado aqui, que poderia, por este rumo, ter sido encerrado ao fim do antepenúltimo parágrafo, com a gargalhada de Bibi.

Recebido em 02 de janeiro de 2013

Aprovado em 15 de maio de 2014

Ana Carneiro é pós-doutoranda no PPGAS/MN/UFRJ. E-mail: <anacarcer@ gmail.com>

\section{Notas}

* Este artigo foi desenvolvido graças ao auxílio de uma bolsa Faperj PAPD, como desdobramento de minha tese de doutorado (Cerqueira 2010), defendida no Programa de Pós-Graduação em Antropologia Social do Museu Nacional/UFRJ, sob orientação do prof. Marcio Goldman. A tese foi baseada em pesquisa etnográfica de 16 meses ao longo de três anos, no município de Chapada Gaúcha, ao norte de Minas Gerais. Os nomes presentes neste artigo são todos fictícios.

${ }^{1} \mathrm{O}$ "agregado" ganha do proprietário o direito de morar e plantar em um pedaço da terra e, em troca, deve ao dono uma parcela de sua produção ou tempo de serviço, e sempre um "favor", uma "ajuda". Em geral, o acerto é que a produção do agregado seja "na meia" (metade da produção para cada um, sendo que o agregado dá a semente). A relação de agregado não se perpetuou nas novas gerações, que hoje têm o direito de posse garantido por lei, embora não sejam "herdeiros" (uma diferença ainda bastante marcada em suas elaborações sobre seu povo).

${ }^{2}$ A noção de "conceito nativo" relaciona-se aqui a certa imagem da antropologia como "tradução cultural". Sobre o assunto, ver Asad (1986), Carneiro (no prelo), Goldman (1999), Rosa (1956), Viveiros de Castro (2002, 2004), Wagner (2010 [1975]).

${ }^{3}$ A marcação das falas nativas será feita por meio de vírgula seguida de inicial maiúscula. Este recurso, consagrado pelo escritor José Saramago, justifica-se aqui pela ideia de conceito nativo tal qual mencionada acima. Trata-se de fazer com que o texto explore a brecha criativa permitida pela relação do antropólogo com a fala 
nativa. Um esforço ficcional e não fictício, de acordo com a elaboração de Viveiros de Castro (2002:123): "Meu ponto de vista não pode ser o do nativo, mas o de minha relação com o ponto de vista nativo. O que envolve uma dimensão essencial de ficção, pois se trata de pôr em ressonância interna dois pontos de vista completamente heterogêneos" (grifo meu). As aspas serão utilizadas apenas quando for necessário dar ênfase a um termo ou expressão nativos em favor do meu argumento.

${ }^{4}$ Uma série de outros trabalhos envolvendo abordagens nem sempre próximas desta buscam da mesma maneira observar, nas narrativas orais, práticas classificatórias ou cosmológicas que dizem respeito ao sistema de pensamento nativo, como é o caso aqui. A título de exemplo, vale mencionar Cardoso (2007) e Lima (2003). Por outro lado, a investigação da oralidade como fonte de um saber histórico, cujo foco está na transmissão de uma memória e em função do estabelecimento de uma identidade individual ou de grupo, constitui um campo de saber bem estabelecido. Boas análises são encontradas em trabalhos como os dos consagrados Bourdieu (1986) e Halbwachs (1990), e em etnografias como as de Ferraz (2012), Hartmann (2007, 2012), Kofes e Piscitelli (1997) e Langdon (2007), Ramos (2009). De uma perspectiva histórica, conferir Perrot (1984).

${ }^{5}$ Por um caminho inverso, esta preocupação pode levar a interessantes análises sobre a apropriação das formas orais pela escrita literária, como fez Patrícia Carmello (2013) em sua abordagem sobre o romance Grande Sertão: veredas, de João Guimarães Rosa, construído, entende a autora, "entre uma concepção de memória individual, ligada à forma do romance moderno; e a memória coletiva ligada à narrativa épica" (Carmello 2013:11).

${ }^{6}$ Esta "animação" da dinâmica de prosa buraqueira deve ser estendida, como em todo o artigo, a uma vaga área que podemos denominar, na falta de termo melhor, onde moram os "povos do Grande Sertão Veredas", a exemplo do nome dado ao encontro anual em Chapada Gaúcha, realizado por Ongs e prefeitura. Em seu trabalho sobre o assentamento da população deslocada por conta da criação do Parque Grande Sertão Veredas (área que inclui parte do município de Chapada), Camila Medeiros (2011) descreve a transformação de uma vida sem cercas, "no tempo do parque", para uma vida "apertada", em que os lotes divididos remetem-nos a um modo de vida com menos "rastros de quem anda". Esta ideia está fortemente relacionada ao modo de vida descrito aqui e suas articulações com a forma narrativa do causo.

${ }^{7} \mathrm{O}$ "afeto" não deve aqui ser confundido com uma ideia amorosa que o termo pode sugerir, mas antes à condição etnográfica que Jeanne Favret-Saada (1990) definiu pela expressão "ser afetado".

${ }^{8}$ Um aspecto notável da noção de "tempo" empregada nestes contextos é muito bem elaborada por Moacir Palmeira e Beatriz Heredia (1997) a respeito da expressão "tempo da política", encontrada em diversas pesquisas realizadas no Nordeste. Este "tempo" tem a característica de se estender para além do tempo dos acontecimentos que lhes são diretamente atribuídos. Os causos e as análises que tais eventos geram continuam sendo efetuados, produzindo efeitos através dos tempos (embora com intensidades diversas). Daí a dificuldade em circunscrever esse período a um calendário fixo; daí também a 
constante "invasão do cotidiano pela política" (Palmeira \& Heredia 1997:177). Neste sentido, as visitas buraqueiras não apenas são a melhor situação para se contar e ouvir causos, mas também são geradoras e elas mesmas objeto de causos no futuro.

${ }^{9}$ A expressão é usada por De Certeau (1990:42-51) em sua reflexão sobre a noção de "cálculo", curiosamente aproximada das de Guattari (1989), Lévy (1987) e Stengers (2003).

10 "A multiplicidade não deve designar uma combinação de múltiplo e de um, mas, ao contrário, uma organização própria do múltiplo enquanto tal, que não tem necessidade alguma de unidade para fazer um sistema" (Deleuze \& Guattari apud Zourrabichvili 2004:70).

${ }^{11}$ Sobre esta dimensão reflexiva do humor, conferir, entre outros, Carneiro (2014) e Lagrou (2006), Clastres 2003 [1974].

${ }^{12}$ Em um estudo sobre as folias de Urucuia, município próximo da Chapada Gaúcha, Luzimar Pereira (2011) chega a um modelo de equilíbrio instável que nos sugere analogias. Seu caso é relativo ao capitão da folia, cujo poder de autoridade sobre os foliões depende de certo respeito à palavra dos últimos (o capitão não deve, por exemplo, oprimir um folião seu "diante das vistas dos povo"). Como no pêndulo "causo bom"/"pouco causo", observado por Dainese, o poder do capitão depende de sua habilidade em "saber dizer as coisas na hora certa".

\section{Referências bibliográficas}

ASAD, Talal. 1986. "The concept of cultural translation in British Social Anthropology". In: James Clifford; George E. Marcus (orgs.), Writing culture. The poetics and politics of ethnography. Berkeley: University of California Press. pp. 141-164.

BAILEY, F. G. 1971. "Gifts and poison". In: Gifts and poison. Oxford: Basil Blackwell. pp. 1-25.

BAKHTIN, Mikhail Mikhailovich. 1981. The dialogic imagination. Austin: University of Texas Press.

BAUMAN, Richard. 1986. Story, performance and event: contextual studies in oral narrative. Cambridge: Cambridge University Press.

; BRIGGS, Charles. 1990. "Poetics and performance as critical perspective on language and social life". Annual Review of Anthropology, 19:59-88.

BOURDIEU, Pierre. 1986. "L'illusion biographique". Actes de la Recherche en Sciences Sociales, 62-63:69-72.

BRUNER, Edward M. 1986. "Experience and its expressions". In: Victor W. Turner \& Edward M. Bruner (eds.), The anthropology of experience. Chicago: University of Illinois Press. pp. 3-20. 
CARDOSO, Vânia Zikán. 2007. "Narrar o mundo: estórias do 'povo da rua' e a narração do imprevisível". Mana. Estudos de Antropologia Social,13(2):317-345.

CARMELLO, Patrícia. 2013. Memória e esquecimento no Grande Sertão: veredas: travessia e melancolia. Rio de Janeiro: 7Letras.

CARNEIRO, Ana. 2014. "O sistema da mexida de cozinha". In: J. Comerford; G. Dainese \& A. Carneiro (orgs.), Giros etnográficos em Minas Gerais: conflito, casa, comida, prosa, festa, política e o diabo. Rio de Janeiro: 7Letras (no prelo). - 2010. O povo parente dos Buracos: mexida de prosa e cozinha no cerrado nortemineiro. Tese de Doutorado, PPGAS/MN/UFRJ.

- O povo parentes dos Buracos: modo de comer e de conversar. Rio de Janeiro: E-papers (no prelo).

CLASTRES, Pierre. 2003 [1974]. "De que riem os índios?". In: A sociedade contra o Estado-pesquisas de antropologia política. São Paulo: Cosac Naify. pp. 147-169.

COMERFORD, John Cunha. 2012. "Família é assunto". Paper apresentado durante a $28^{\mathrm{a}}$ Reunião Brasileira de Antropologia, na mesa "Família e parentesco. Descentramentos e confluências" (Comunicação pessoal).

- 2003. "Mapeamentos, familiarização e reputações: a sociabilidade agonística na roça". In: Como uma família: sociabilidade, territórios de parentesco e sindicalismo rural. Rio de Janeiro: Relume Dumará. pp. 25-139.

DAINESE, Graziele. 2014. "Chegar à Terceira Margem: hospitalidade, conversas e paixões". In: J. Comerford; G. Dainese \& A. Carneiro (orgs.), Giros etnográficos em Minas Gerais: conflito, casa, comida, prosa, festa, política e o diabo. Rio de Janeiro: 7Letras (no prelo).

DE CERTEAU, Michel. 1990. L'invention du quotidien. vol.1 Arts de faire. Paris: Éditions Gallimard.
- 1988. "The historiographic operation". In: The writing of history. New York: Columbia University Press. pp. 56-111. DELeUZe, Gilles \& GUATTARI, Félix. 1980. Mille plateaux. Paris: Minuit. EDWARDS, Jeanette. 2000. Born and bred. Oxford: Oxford University Press.

FAVRET-SAADA, Jeanne. 1990. "Être affecté". Gradhiva. Revue d'Histoire et d'Archives de l'Anthropologie, 8:3-9.

FERRAZ, Ana Lúcia Marques Camargo. 2012. "Luciane Rosã: os personagens do Circo-Teatro e o recurso à representação de papéis na pesquisa etnográfica". In: M. A. Gonçalves; Roberto Marques \& Vânia Cardoso (orgs.), Etnobiografia: subjetivação e etnografia. Rio de Janeiro: Ed. 7Letras. pp. 137-156.

GOLDMAN, Marcio. 1999. "O que fazer com selvagens, bárbaros e civilizados?". In: Alguma antropologia. Rio de Janeiro: Relume-Dumará / Nuap. pp. 77-82.

GOW, Peter. 1991. Of mixed blood: kinship and history in Peruvian Amazonia. Oxford: Clarendon.

GUATTARI, Félix. 1989. Les trois écologies. Paris: Galilée.

HALBWACHS, Maurice. 1990. A memória coletiva. São Paulo: Revista dos Tribunais Ltda/ Vértice.

HARTMANN, Luciana. 2012. "Tomazito, eu e as narrativas: porque estoy hablando de mi vida". In: M. A. Gonçalves; Roberto Marques \& Vânia Cardoso (orgs.), Etnobiografia: subjetivação e etnografia. Rio de Janeiro: Ed. 7Letras. pp. 179-206. . 2007. "As narrativas pessoais e a constituição dos contadores de causos como sujeitos". In: F. Fischman \& L. Hartmann (orgs.), Donos da palavra: autoria, performance e experiência em narrativas orais na América do Sul. Santa Maria: Ed. da UFSM. pp. 125-164. KOFES, Suely \& PISCITELLI, Adriana. 1977. "Memórias de histórias femininas, memórias e experiências". Cadernos Pagu, 8/9:343-354. 
KRISTEVA, Julia. 1969. Seméiotiké. Paris: Seuil.

1970. Le texte du roman: approche sémiologique d'une structure discoursive transformationnelle. The Hague: Mouton. LAGROU, Els. 2006. "Rir do poder e o poder do riso nas narrativas e performances kaxinawa". Revista de Antropologia da USP, 49(1):54-90.

LANGDON, Jean. 2007. "Dialogicidade, conflito e memória na etno-história dos Siona". In: F. Fischman \& L. Hartmann (orgs.), Donos da palavra: autoria, performance e experiência em narrativas orais na América do Sul. Santa Maria: Ed. da UFSM. pp. 17-40.

LÉVY, Pierre. 1987. "Le paradigme du calcul". In: I. Stengers (org.), D'une science à l'autre. Paris: Éditions du Seuil. pp. 88-118.

LÉVI-STRAUSS, Claude. 1971. L'homme $n u$. Paris: Librairie Plon.

_ 1968. L'origine des manières de table. Paris: Librairie Plon.

_ 1967. Du miel aux cendres. Paris: Librairie Plon.

. 1964. Le cru et le cuit. Paris: Librairie Plon.

LIMA, Nei Clara de. 2003. Narrativas orais: uma poética da vida social. Brasília: Editora Universidade de Brasília.

MANNHEIM, Bruce \& VAN VLEET, Krista. 1998. "The dialogics of southern Quechua narrative". American Anthropologist, 100(2):326-346.

MEDEIROS, Camila. 2011. No rastro de quem anda: comparações entre o tempo do Parque e o hoje em um assentamento no noroeste mineiro. Tese de Doutorado, PPGAS/MN/UFRJ.

PALMEIRA, Moacir \& HEREDIA, Beatriz. 1997. "Política ambígua". In: P. Birman; R. Novaes \& C. Samira (orgs.), O mal à brasileira. Rio de Janeiro: EdUERJ. pp. 159-184. PEREIRA, Luzimar. 2011. Os giros do sagrado: um estudo etnográfico sobre as folias em Urucuia, MG. Rio de Janeiro: 7Letras.
PERROT, Michele. 1984. "Les sources orales pour l'histoire des femmes". In: Une histoire des femmes, est-elle possible? Paris: Rivages. pp. 60-70.

RAMOS, Danilo Paiva. 2009. Nervos da terra: histórias de assombração e política entre os sem-terra de Itapetininga - SP. São Paulo: Annablume.

ROSA, G. 1956. "Prefácio". In: P. Rónai (org.), Antologia do conto húngaro. Rio de Janeiro: Artenova. pp. XXV-VI. SAHLINS, M. 1997. "O 'pessimismo sentimental' e a experiência etnográfica: por que a cultura não é um 'objeto em via de extinção'". Mana. Estudos de Antropologia Social, 3(1):41-75.

SILVERSTEIN, Michael \& URBAN, Greg. 1996. "The secret life of texts". In: Natural histories of discourse. Chicago: University of Chicago Press. pp. 81-105. STENGERS, Isabelle. 2003. "Calculemus". In: Cosmopolitiques II. Paris: La Découverte. pp. 376-389.

STRATHERN, Marilyn. 1999. "No limite de uma certa linguagem" (entrevista com Eduardo Viveiros de Castro e Carlos Fausto). Mana. Estudos de Antropologia Social, 5(2):157-175.

VANZOLINI, Marina. 2013. "As histórias dos outros: variação mítica e mentira no mundo Aweti do Alto Xingu" (Comunicação pessoal).

VIVEIROS DE CASTRO, Eduardo. 2004. "Perspectival anthropology and the method of controlled equivocation". Paper apresentado em Meeting of the Society for the Anthropology of Lowland South America (SALSA), Florida International University, Miami, jan. 17-18. Mimeo.

. 2002. "O nativo relativo". Mana. Estudos de Antropologia Social, 8(1):113-148.

WAGNER, Roy. 2010 [1975]. A invenção da cultura. São Paulo: Cosac Naify. ZOURRABICHVILI, F. 2004. O vocabulário de Deleuze. Rio de Janeiro: RelumeDumará. 


\section{Resumo}

Com foco na circulação de prosa do povo dos Buracos, ao norte de Minas Gerais, exploro a articulação entre os termos "povo" e "causo", com ênfase no último. Os causos - dizem os buraqueiros - ensinam sobre o povo. Com o intuito de tratar ambos os termos como conceitos nativos, questiono: Que espécie de conhecimento é conceituado pelo causo? Que forma de pensamento ele efetua sobre aquele povo? O que é um causo, afinal? Não se trata de buscar delimitações para esta forma narrativa, pois ela pode consistir tanto em frases curtas quanto em preleções de horas. Investigo, antes, as suas práticas criativas, isto é, as conversas triviais e as configurações relacionais contingentes das quais o causo surge. Descrevo como o narrador, ao contar sobre o povo, cria, qualifica, aproxima ou distancia as relações entre ele, os narrados e os ouvintes, atuando em um constante movimento de transformação do arranjo em que se constitui o povo. Por fim, analiso "o causo da televisão de dona Bibi" à luz das reflexões ora mencionadas.

Palavras-chave Narrativa oral, Parentesco, Escrita etnográfica, Sertão norte-mineiro.

\section{Abstract}

In this article, I explore articulations formed through the terms povo (a people) and causo (a yarn or story), with an emphasis on the latter, by looking at the exchange of prosa (conversations) among the Buracos' people - the Buraqueiros - in the North of Minas Gerais, Southeastern Brazil. The Buraqueiros say that yarns teach us about the people. And in order to treat both these terms as native concepts, the article asks: What type of knowledge does the yarn conceptualise? What type of logic does it generate among these people? What is a yarn, in the end? The aim is not to seek circumscriptions for this narrative form, for it appears both as short remarks and lengthy lectures. Instead, I investigate its creative practices, the trivial conversations and relational configuration from which the yarn emerges. I shall describe how, when he tells of a people, the narrator creates, qualifies and intensifies or diverges relations between himself, protagonists and listeners, acting in a constant movement that transforms the arrangements through which a people are constituted. I conclude by using these reflections to analyse "Dona Bibi's yarn about the television".

Key words Oral narrative, Kinship, Ethnographic writing, the Northern Mineiro Sertão. 